\title{
Nigeria: \\ Conflict Victims' Assessment and Narratives on the Reportage of Herdsmen-Farmers Conflict
}

\author{
Oberiri Destiny APUKE \\ Bahiyah OMAR
}

\begin{abstract}
Nigeria has witnessed many violent clashes caused by herdsmen-farmers conflict. While past research has focused on media coverage of the conflict, conflict victims have seldom become the subject of investigation. This study attempts to understand the conflict victims' assessment and narratives on the reportage of herdsmen-farmers conflict in Nigeria. Sixty (60) participants were interviewed from three (3) large communities in the North Central region of Nigeria. There is a prevailing view that the herdsmen and farmers conflict has not been given prominence by conventional media in Nigeria and the reportage of the conflict often disappear once the clashes subdue. This study considers conflict victims' assessment on the objectivity, depth and outcome of media coverage of the conflict. It was found that Nigerian media do not report actual narratives of conflict victims, as
\end{abstract} reporters often rely on second hand stories and do not present themselves at the locations to gather news. Conflict victims, hence, claim that the Nigerian media suffers from lack of objectivity and high sensationalism. They also found that excessive use of negative language, which often indicate blame game, contributes to the escalation of the conflict. This calls for an urgent need for socially responsible journalists in Nigeria who promote messages of reconciliation, negotiation and diplomacy when reporting the herdsmen and farmers conflict.

Keywords: Conflict, conflict reporting, conflict victims, herdsmen-farmers conflict, media coverage, Nigeria.

\author{
Oberiri Destiny APUKE \\ School of Communication, \\ University Sains Malaysia \\ Department of Mass Communication, \\ Taraba State University, Nigeria \\ E-mail: apukedestiny@gmail.com \\ Bahiyah OMAR \\ School of Communication, \\ University Sains Malaysia \\ E-mail: bahiyah@usm.my \\ Conflict Studies Quarterly
}

Issue 31, April 2020, pp. 22-40

DOI:10.24193/csq.31.2

Published First Online: 05/04/2020 


\section{Introduction}

Conflict constitutes one of the greatest challenges to social, political and economic development of any society (Shehu, 2017). Since 1999, Nigeria has been a theatre of violence conflict in which between 1999 to 2002, witnessed over forty ethno-religious and communal conflict (Odunlami, 2017). These conflicts have been exacerbated with the raging battle between Fulani herdsmen and farmers of Nigeria's North Central region, though the problem remains spread across different parts of the country (Ciboh, 2015). Studies report that these violent clashes, apart from the human casualties, have cost the nation over 14 billion dollars between 2012 and 2015. In 2014 alone, 1,229 people were killed, 63 deaths were recorded in 2013, 500 deaths by July 2016, and about 73 were given mass burials in Benue state of Nigeria, and yet there is no sign of these occurrences stopping (Beetseh et al., 2018; Odunlami, 2017). The conflict as documented in other research, has uprooted more than 100,000 people in Benue and Enugu states, and many are staying with relatives or in makeshift internally displaced person's camps. The bursts of violence have displaced 400,000 people in the last five years while many are still struggling to rebuild their lives (Idowu, 2017).

The Fulani herdsmen or Fulani pastoralists are nomadic or semi nomadic herders whose primary occupation is raising livestock. The pure Fulani pastoralist engages in random movement of cattle while the semi-nomadic makes transhumance migration and return to their camps or homes (Okello et al., 2014). Consequently, the perennial clash between farmers and herdsmen has been mostly traced to resource scarcity where both herders and farmers rely on for their livelihood (Shehu, 2017; Gever \& Essien, 2019). Other factors that contribute largely to the notoriety of the herdsmen attacks across the country has been attributed to political, religious, ethnic, economic, land tenure system and historical feuds (Adamu, 2017b). It is a known fact that the herdsmen-farmers conflict has a negative implication for the economy growth of Nigeria and thus press coverage which has been described as the amount of media attention given to a particular issue as well as the manner in which such issues are reported is very essential (Abdulbaqi \& Ariemu, 2017).

Accordingly, it has been shown that the media are by far the most important source of information about conflicts for most people, which grants them a considerable influence over citizens' perceptions, opinions and behaviour (Shehu, 2017). By reporting on some conflicts, but not on others, and by representing conflicts in particular ways, the media strongly influence the dynamics and outcomes of conflicts, and thus also shape the prospects of success of conflict parties (Vladisavljević, 2015). Specifically, in Nigeria, there is evidence to show that some media only facilitate the escalation of conflicts and this problem has cast doubts in the minds of both Christians and Muslims on the proper role of media reportage during ethno-religious conflicts (Barde, 2016). Undoubtedly, the media are saddled with the responsibility of bringing to people issues 
they have to be informed about in which the herdsmen-farmers conflict is one of such (Udeze \& Chukwuma, 2016). However, the manner of their reportage of these issues may either escalate or deescalate the conflict (Vladisavljević, 2015). Intrinsically, reporting ethno-religious conflict is one of the delicate and sensitive areas in journalism, which requires professionalism, objectivity and patriotism (Barde, 2016).

Despite the considerable articles written about the crisis on herdsmen and farmers and the role mass media have played,surprisingly, there is a dearth of research on people's perception as regards the media coverage of herdsmen and farmers conflict in Nigeria (Adamu, 2017a). Though commendable, most studies on the media coverage of herdsmen and farmers, conflict have been examined through the lens of a content analysis,that is critiquing content and it has been shown that one limitation inherent in all content analyses is the inability to explain the impact of the media messages on the consumers (Flynn et al., 2016). Additionally, there are studies that have also attempted to explore the phenomenon historically, as well as exploring the causes and implication of the conflict to the society. Nevertheless, since the way the conflict is reported goes a long way in either assuaging or provoking the parties involved (Adamu, 2017a, 2017b, Akpan et al., 2013), there is an urgent need to explore the way, such reportage and coverage are perceived by the conflict victims and actors beyond merely critiquing the content of the media (Beetseh et al., 2018).

Therefore, this study seeks to address this gap, by appraising the conflict victims' perception and attitude toward mass media reportage of farmers and herdsmen conflict in Nigeria. This study will bring to our understanding evidences from the rural communities that face the issues of these conflicts, if the media in Nigeria are one sided in its coverage of the conflict, if its reportage escalate or deescalate the conflict as well as know if it really gives prominence and depth in coverage. The result will be an addition to the literature on people's perception of conflict as reported by the mass media, especially in rural areas of developing countries. The findings will also assist government and policy makers to initiate policies that will ensure effective mass media reportage of conflict so as to minimize the escalation of conflict.

\section{Aim and objectives of the study}

The main aim of this research is to understand the conflict victims' assessment and narratives on the reportage of herdsmen-farmers conflict in Nigeria. This aim is achieved via the following objectives:

- To find out from the conflict victims' if the media give prominence to the conflict.

- To determine the conflict victims' view on the coverage of the issue based on when the conflict was ongoing and when it is subsided.

- To know the conflict victims' perception of the objectivity and factuality of media coverage of the herdsmen -farmers Conflict. 
- To realize the conflict victims' views on whether the coverage of the herdsmen and farmers conflict escalate or deescalate the conflict.

- To determine from the conflict victims' if the media report the suffering faced by them.

\section{An overview of farmers and herdsmen conflict in Nigeria}

The conflicts between farmers and herdsmen in Nigeria has been very frequent, and most predominantly in the North Central, resulting in serious consequences to include loss of property worth billions, displacement of people from their residents, killing of cattle's, and many more (Beetseh et al., 2018). Most times, the farmers are overpowered, injured and killed, while others are evicted from their homes. Sometimes, the herdsmen are accused of taking these opportunities to steal, rape, raze houses and kill innocent members of the communities they pass through (Akinkuolie, 2018; Beetseh et al., 2018). There are six states that formed the North Central Nigeria and this include Benue, Niger, Nasarawa, Plateau, Kogi and Kwara and these states have experienced conflicts at different points(Abdulbaqi \& Ariemu, 2017). These conflicts have also extended to the Nigerian middle states such as Taraba (Oladimeji et al., 2015).

Although the herdsmen have been known to carry out attacks on certain communities in Nigeria, the rate at which such atrocities are committed now has escalated. For example, in February 2018, more than 40 people were killed, about 2,000 displaced and not less than 100 sustained serious injury (Gever \& Essien, 2019). More recently, about 92 Nigerians were killed by the suspected Fulani herdsmen in Benue state (Beetseh et al., 2018), demonstrating the complexities of these conflicts in Nigeria (Abdulbaqi \& Ariemu, 2017).This corroborates evidence which shows that in 2014 alone, 1,229 people were killed, 63 deaths were noted in 2013, 500 deaths by July 2016, and about 73 were massacred in Benue State of Nigeria (Beetseh et al., 2018). This conflict has displaced more than 100,000 people in Benue and Enugu states (Odunlami, 2017). The bursts of violence have also displaced about 400,000 people in the last five years (Idowu, 2017). In December 2015, it was reported that more than 22 people were killed by the suspected herdsmen in Jos, and 300 persons were attacked and killed in Benue as at February 2016. Similar attacks have also been reported in Kaduna, Zamfara, Nasarawa and this has been increasing on a daily basis (Shehu, 2017).

Ojewunmi (2013) noted that there was a violent outbreak between the Fulani and Tarok in Wase Local Government Area which resulted in 20 people dead. It is not surprising that the Global terrorism index regarded the herdsmen as the fourth deadliest militant group in the world with a documented killing of about 1229 people in 2014 alone (Gever \& Essien, 2019). Prior research has also shown that Kwara and Kogi states have witnessed farmers/herdsmen conflict. For example, Marietu and Olarewaju (2009) described Kogi conflict as one of the factors responsible for the unsustainable usage of 
land and water resources. The authors added that this conflict has resulted in loss of crop yields, loss of economic plants, water pollution, loss of soil fertility and loss of fishes.

As regards the causes of farmers and herdsmen clashes, Adisa and Adekunle (2010) sampled both farmers and herdsmen, and found that inadequate knowledge of stock routes, depleting soil fertility and the need to expand the scale of operation by both groups increases the conflicts. In the same survey, farmers and herdsmen accused themselves of destroying their farm lands and cultivating on farmland that is not meant for farming respectively. More recent studies have shown that the perennial clash between farmers and herdsmen are mostly traced to resource scarcity, political, religious, ethnic, economic, land tenure system and historical feuds (Shehu, 2017; Gever \& Essien, 2019; Adamu, 2017b).

Thus, the general implication of the conflict holds a critical and negative implication for the growth of Nigeria and its citizens (Gever \& Essien, 2019). The claim of the natives (farmers) to the exclusive right of land ownership is contrary to the constitutional provision of inclusive citizenship, which suggests that every citizen of Nigeria has the right of settlement in any part of the country. Gever and Essien (2019) conclude that the extent of crisis and violence that has characterized the conflict, is an enemy of sustainable development both in the affected communities and Nigeria as a whole.

\section{Relationship between media and conflict reporting}

The stories reported in the media constitute a pertinent source of information for citizens about certain events in the society and this contributes to the societal structure of reality (Ross, 2007). As such, the content of the media not only provides the unknown to the audience, but extends to the confirmation or disconfirmation of reality about what is already known and witnessed (Dauda \& Omar, 2015; Sundin, 2015).Conflict is a major news value to the media and, as such, remains foremost fodder for media (Himelfarb \& Chabalowski, 2008). No doubt there is anassociation between media and conflict and over the last decade, reporting of farmer-herder violence has increased exponentially in the media, and this calls for social responsibility. Social responsibility is the obligation of the media to act for the benefit of the society at large. Thus, the rationale for reporting conflict has been shown to include the creation of awareness of a conflict to avoid escalation, in turn, helping religion and community leaders resolves conflicts; generating ideas on how best to reduce conflict; exposing the perpetrators and sponsors of conflict; de-escalating rather than to increase the conflict; to attract humanitarian responses through publicizing yearning of aspirations of victims; and to provide early warning to law enforcement agencies and stakeholders so as to halt an incoming conflict (Pate, 2002). All these suggest that conflict reporting requires professionalism, because unprofessional reporting of conflict might increase the likelihood of conflict. 
According to Vladisavljević (2015), the media strongly influence the outcomes of conflict, in turn, shaping the prospects of success of the conflict parties. This implies that the media could stay detached by simply presenting issues with facts objectively or take sides, thereby affecting the salience of conflicts, public opinion and public policy at large (Althaus \& Tewksbury, 2002). Studies on the role of media in constructing conflicts reports that the media rarely cover conflicts with neutrality, and conflicts could be promoted through negative coverage that promote hate speech, incendiary rumors, deliberate underreporting and misreporting, over reporting and sensationalism, while it could be reduced by reporting stories that centers on peace and security which in turn could change attitudes and behaviors of actors of the conflict (Pate \& Dauda, 2015; Zeng et al., 2014).

Gilboa (2009) stressed the essence of professionalism in conflict reporting, urging media practitioners to gather information and report them responsibly, because the media play a critical role in the prevention and management of conflict as well as deliberately promotes conflict. According to Udeze and Chukwuma (2016), "amongst the core responsibilities of the mass media, surveillance function takes a critical role", suggesting that media are saddled with the responsibilities of letting the public know about in coming dangers through covering, analysing and reporting impending dangers that pose threat to the livelihood and lives of people in general. Does the Nigerian media adhere to these suggestions? This forms part of what this current study seeks to determine.

\section{Media and conflict reporting in Nigeria}

Research evidence has shown that, in Nigeria, media reporting of especially inter-group conflicts has been associated with unprofessional acts of sensationalism, considerations of context, inaccuracy and unfairness, imbalance and incompleteness, as well as less integrity and responsibility (Ciboh, 2015). This implies that many press reports on issues, particularly ethnic conflicts, are distorted and coloured with ethnic prejudice which now divides the Nigerian press into a north-south press. This is consistent with Geverand Essien's (2019) study that examined newspaper coverage of farmers and herdsmen conflict in Benue state and found that the sampled newspapers, mostly reported straight news and only covered the conflict when it happens with little attention given to the conflict when it subsides.

Similarly, Shehu (2017) found that newspapers in Nigeria framed the Fulani herdsmen in a demonizing manner, suggesting that, Fulani herdsmen are portrayed as stubborn and unforgiving and the demonization of the Fulani as a tribe may not help in extenuating the conflict. Rather, it will spread the hatred of the tribe to all parts of Nigeria, thereby escalating the conflict and pushing the country further into the danger spot. This corroborates another content analysis on the Punch, Vanguard, Daily Trust and Leadership Newspapers which found that reports on herdsmen-farmers conflicts are 
more violent, specific and narrowed featuring words like 'killers' herdsmen', 'gun-carrying herdsmen', 'Jihadist herdsmen', 'greedy farmers', 'intolerable farmers' and so on (Abdulbaqi \& Ariemu, 2017). These words are more typical of war-oriented journalism than peace-oriented journalism that favours non-violent approach to conflict. What then are the audience view as regards the coverage of herdsmen and farmers conflict constituted the basis of this current research since it has been seen from this review that most of the studies on media coverage of herdsmen and farmers have dwelled on critiquing media content.

\section{Theoretical underpinning}

This current study is anchored on agenda setting and social responsibility theory. Agenda setting which was propounded by Maxwell McCombs and Donald Shawn in 1972 has been described as the ability of the news media to influence and ascribe importance a topic in the society (Reynolds \& McCombs, 2002). This infers that if the news media cover an issue frequently and with prominence the public will view that issue as important (Apuke, 2018; Dauda \& Omar, 2015). According to Folarin (1998), the media predetermine what issues to consider and media do this through factors like frequency of reports,the prominence given to the reports through headline display, pictures, and layout in newspapers, magazines, films, graphics or timing on radio and television.

On the other hand, the social responsibility theory was proposed in 1947 by the Hutchins Commission of Inquiry. Based on the theory, the media have freedom to publicize but must put into cognizance responsibility to the society at large (McQuail, 2010). Relating these two theories to the study, it could be said that journalists are mandated to give an accurate account of the farmers and herdsmen's conflict as well as give prominence and adequate frequency to the stories so that people will be on guard. The reports of the media should not be one sided, but instead contribute in resolving the conflicts than escalating it.

\section{Methods \\ Study design}

This study made use of the qualitative research design following the phenomenological approach described by (Stake, 2013; Braun \& Clarke, 2013). Interviews were conducted among 60 conveniently selected participants. The interview technique was used because it allows for sufficient freedom and depth of probing. This method has been shown to permit participants to describe their feelings in their own words and new themes could be followed up as they emerged. It was also felt necessary to develop a contextbased understanding as regards media coverage of herdsmen and farmers conflict in Nigeria. In keeping with the general practice of qualitative research, the participants were assured anonymity along with their communities, in order to encourage them to 
discuss pertinent issues in depth and in detail (Kontagora et al., 2018). For example, the participants were coded as participant $1,23 \ldots 60$.

\section{Participants and sampling}

Of the six states in north central Nigeria, we purposefully selected three states, namely Benue, Plateau and Nasarawa, that were highly affected by the conflict in recent years. After states selection, we zoomed into their local governments to reach out to the sample of the study. All local state governments (LGA) under the three states were identified; Benue has 23 (LGA), Plateau has 17 (LGA), and Nasarawa has 13 (LGA). A random selection was conducted by numbering all the (LGA) and placing the numbers in three different boxes and later randomly picked one (LGA) from each box. At the end, three (LGA) were selected; Eggonfor Nasarawa, Bokkos North for Plateau, and Gboko for Benue. From each selected (LGA), we recruited twenty participants who volunteered to participate in the interview. These communities have witness's series of conflict between herdsmen and farmers, so it is believed that responses from the selected communities will provide a richer insight into the problem being investigated. Overall, it has been shown that the North Central region of the country appears to be the hotbed of these conflicts (Ciboh, 2015).

In this study, conflict victims and survivors are defined as those who stated they have continuously experienced the clashes that has happened between the herdsmen and farmers. They could also be called eyewitness who are present at an event and can therefore describe it. They have been harmed, injured, or lost loved ones as a result of the communal clash. They feel helpless and passive in the face of misfortune. These victims cut across both the farmers and the Fulani's. In a nutshell, two criteria were set for inclusion; participants must be regularly exposed to the media (e.g., radio, television and newspapers) and participants must have experienced the conflict to a large extent. Based on these criteria, 60 participants, 20 each were recruited from the three communities. Participation was voluntary, therefore, those who were readily available were used. Of the 60 participants, it was observed that male $(n=40)$ were more than the female $(n=20)$. More than half of the participants were between 30 and above $(n=40)$ and the rest were between the ages of 18-29 $(n=20)$. A large number of the respondents had formal education $(n=45)$ while only a few indicated that they had no formal education $(n=15)$ but could still communicate in English. So, the researchers used simple English in the interview session.

\section{Data collection procedure}

Data were collected through Face-to-face semi-structured interviews, and all interviews were recorded. The Interviews were conducted in the early months of 2019 and lasted for approximately 8 weeks to finish. The interviews were semi-structured to ensure 
consistency while also allowing particular experiences and matters to be explored in larger detail. To ensure the validity of the interview script, the interview questions were pretested on four $(n=4)$ participants outside the initial sampled participants. For further scrutiny and review of the questions, the researchers consulted two experts in the field of communication and conflict management. The individual interviews were facilitated by three experienced research assistants who were trained in qualitative research methodology. Before the interview started, the participants signed a consent form. In addition, approval was also obtained from the community leaders.

Each interview lasted for about 20-60 minutes to complete and were recorded and transcribed verbatim. The researchers also took notes which enabled the documentation of the participant's facial expressions such as a frown, head nodding and sighing. The main points were also summarized at the end of each interview in order to ensure its accuracy and fairness and to give participants the opportunity to add to or correct the notes (Kontagora et al., 2018). The participants were asked their view on the objectivity of media coverage of herdsmen and farmers Conflict, whether the coverage of the herdsmen and farmers conflict escalate or deescalate the conflict, if the media report the suffering faced by victims of the conflict, if the media give prominence to the conflict. They were further asked their view on the coverage of the issue based on when the conflict was ongoing and when it subsided.

\section{Data analysis}

To examine the qualitative data received from the interview sessions. The six thematic data analysis steps identified by Braun and Clarke (2013:175) were employed. These entail the researchers transcribing the recorded interviews; rereading the transcriptions to identify emerging themes from the recorded data; reviewing the themes; defining the themes; naming the themes, and lastly writes the outcomes. The assistants recruited for this investigation, paid extensive attention to each step, beginning with the careful arranging of the taped interviews. Thenceforth, the transcriptions were attentively reread to identify emerging themes from the recorded information. The findings were then discussed and interpreted thematically along with the results of the existing literature. This technique is consistent with prior studies (Braun \& Clarke, 2006; Parajuli \& Doneys, 2017).

\section{Results and discussion}

This section presents the findings adopting 'realistic' style of reporting, according to the themes that emerged (Gorman et al., 2005). Since the aim of this research was to understand the public's view, the findings from the three sampled communities were not presented separately. 


\section{Low prominence given to herdsmen-farmers conflict in media}

The respondents were asked to comment on the Nigerian media allocation of prominence to the issue of herdsmen and farmers conflict. The entire respondents claim that the Nigerian conventional media do not allocate much prominence to the issue of herdsmen and farmers conflict. They questioned the depth of coverage of the issues relating to the conflict and that only a few seconds are mostly allocated for TV and Radio, while for print the issue of conflict are sparingly reported on the front pages of the newspapers. In this regard, one of the sampled community dwellers said:

I am always glued to my radio sets, and I have come to realize that there are more stories on politics than the issue of farmers and herdsmen conflict that is destroying our means of livelihood. I remember, there was a time when we were attacked in our farms and the national Television NTA did not air such attack. (Participant 1)

An overwhelming number of the interviewed rural dwellers commented that the private media in Nigeria to an extent cover the issues relating to the conflict more than the government own media and Radio was ranked as the first media that covers the issue of the conflict more than any other conventional media outlet in Nigeria. In line with this claim, one of the participants commented that:

I am exposed to Radio, TV and Newspapers in Nigeria and I will boldly say that since we started experiencing the farmers and herdsmen conflict, Radio stations have been more vibrant in the reportage. Newspapers are also trying their best. (Participant 5)

Many of the respondents recognized and acknowledge that the new media such as blogs, Facebook, Twitter, etc., which has given rise to citizen journalism seem to cover the issues of the conflict more than the conventional media in Nigeria. They emphasized that the conventional media are more into political news than the conflict which is ravaging most communities in the North central Nigeria. They noted that the use of blogs and other forms of new media outlet to cover the issues of conflict is made more possible because the new media is a shift from the hypodermic needle assumption of one-way communication. Thus, they use blogs, Facebook and Twitter deliver news almost at the velocity of light, unlike the broadcast media. In line with this claim, one of the respondents commented that:

Through blogs, Twitter and Facebook news spreads like wild Harmattan fire in split seconds, because the word does not need to wait for any editor to process it, and feedback is prompt. The public receives the chance to respond to the news instantly, and even contribute to the content. This is helpful in the reportage of herdsmen and farmers conflict which go a long way of informing the people. (Participant 10) 
The whole respondents had the strong conviction that due to the new media content source and distribution which could even permit them who are conflict victims post their issues, it is believed that it gives more advantage than the mainstream media in Nigeria. They also acknowledge that blogs, Twitter and Facebook promote non-commercial journalism that propagates the interests and yearning of those excluded from the mainstream. They listed some blogs in Nigeria that have been helpful in the coverage of their issues to include Naijapals.com, Naija.com, Sahara reporters, and Naija Community among many others. According to a respondent:

Blogs, Twitter and Facebook are independent of corporate control, and therefore reporting stories has been made easier, I believe that the conflict stories

in its factual state may be more disseminated to the public. (Participant 60)

Although the respondent also expressed their disapproval on some stories posted on blogs and other forms of the new media, nevertheless, they strongly had the notion that these platforms are doing far better than the conventional media in Nigeria and should be promoted and encouraged.

Based on the above comments, it could be deduced that the Nigerian media are yet to give prominence to the issue of herdsmen and farmers conflict. However, the private media seem to allocate more prominence than the government media stations and overall, among the conventional media, radio stations according to the respondents give more prominence to the issues of herdsmen and farmers conflict in Nigeria. This result validates the claim which suggests that the mass media in Nigeria have not been timely in their reportage of conflicts and insurgencies (Afolabi, 2010). In addition, this finding extends prior studies that have mostly examined the issues of herdsmen and farmers conflict through Newspaper coverage, as it demonstrates that Radio as stated by the respondents play a huge role in the reportage of the conflict in Nigeria. Drawing from the agenda setting premise, if the news media cover an issue frequently and with prominence the public will view that issue as important (Apuke, 2018).Amazingly, the comments above also pointed out that the new media such as blogs, Facebook, Twitter, etc., which has given rise to citizen journalism seem to cover the issues of the conflict more than the conventional media in Nigeria.

\section{Episodic reporting of herdsmen-farmers conflict based on ongoing clashes}

Most of the respondents testified that the media mostly cover the conflict when it is on but, as soon as the conflict is over, little or no attention is paid to other issues on the conflicts. They remarked that the conventional media in Nigeria reports base on episodes than thematically. In this regard, a respondent commented that:

I have noticed that media in Nigeria are more after politics than reporting of conflict, they report conflict when its ongoing, however, when the conflict has 
subsided, they don't do follow up stories that will enable the public know the rationale for the conflict, I believe that if the media do a follow up investigation and report they will be able to expose those who reportedly collect money from the herders, those who are truly causing the conflict, those who sponsor the conflict, as well as the allegations of cattle rustling and farm encroachment. (Participant 15)

This suggests that Nigerian media have less interest in the coverage of conflict which is contrary to the social responsibility of the press. This result validates the research of Gever and Essien (2019) who examined newspaper coverage of farmers and herdsmen conflict in Benue state and found that the newspaper mostly reported straight news and only covered the conflict when it happens with little attention given to the conflict when it subsides.

\section{Lack of objectivity and low factuality in media coverage of herdsmen-farmers conflict}

The entire respondents specified that the conventional media in Nigeria do not cover the issues of herdsmen and farmers in an objective manner. They remarked that journalists most times do not even come to their community to cover stories, yet, they are surprised to hear some conflicts reported in the media. They believe that the journalists get second hand stories from security agencies and this affects their reportage, because they are supposed to be on the spot after a clash so as to interview the victims and get an accurate account of stories. A large number of the respondents alleged that the actual narratives of conflict victims are not covered by the media in Nigeria. Suggesting a lack of investigative reporting. The respondents also observed that media practitioners in Nigeria mostly interview either the farmers or herdsmen without hearing from both sides and this has resulted in sensationalized reporting. While rating the media in Nigeria in terms of objectivity, the respondents stated that the newspapers in Nigeria seem to be more objective in reporting the conflict than the Radio and TV. In this regard, a respondent stated that:

The media in Nigeria is characterised by one sided reporting and lack objectivity in their reportage. They are more after blaming than proffering solution and this goes a long way to affect the outcome of the conflict. (Participant 8)

Supporting this notion another respondent who was a Fulani remarked that:

There are no neutrality and factuality in the Nigerian media reportage of farmers and herdsmen conflict in Nigeria. The stories are mostly taking sides of the farmers against the herdsmen, that is why most of the headlines describe the herdsmen as evil and deadly. (Participant 42) 
The respondents further expressed that the conventional media most especially, the government media do not cover the issues of the conflict objectively in order not to implicate those in power. Indeed, portraying the issues of the conflict in a more truthful manner would inform the public on the extent at which the government is intervening, and in turn will demonstrate the competence or incompetence of the government. Sadly, the government-owned mainstream media are mostly sceptical when it comes to criticism of the government in power, while the private media who rely mostly on profit through various funders, advertisers and special interest groups would not be far from unbiased reporting. According to one respondent:

The actual stories of the conflict are not adequately covered and disseminated and are usually lost in statistics and reports of humanitarian responses. As such, Nigerian media are characterized by manipulation and distortion to suit the ideology or political agenda of the nation, as well as the media house or prominent individuals. (Participant 30)

The participants also mentioned the issue of factuality. They remarked that the media in Nigeria do not report the actual number of death rates when a clash occurs and sometimes, they blow the number of death rate out of proportion. Accordingly, one participant stated that:

In the early months of last year our village was attacked and many lives and properties were lost, but the media reported the death rate to be 16 , while the death rate was more than 50 . This shows that the media are not factual in reporting the issues of the conflict. (Participant 31)

Another respondent remarked that:

Our village was attacked and the media reported it as unknown gunmen while it was herdsmen that perpetrated such evil. This goes to show how lazy the Nigerian media could be in their watch dog and surveillance function. (Participant 6)

These comments suggest that the Nigerian media are lacking in objective and factual reporting as well as not carrying out their surveillance and watchdog function. This supports studies on the role of media in constructing conflicts which reports that the media rarely cover conflicts with neutrality (Pate \& Dauda, 2015; Zeng et al., 2014) and that media mostly resort to the allocation of blame which result to the building of enmity among groups of people (Ozuhu-Sulaiman, 2013). According to Vladisavljević (2015), the media strongly influence the outcomes of conflict, in turn, shaping the prospects of success of the conflict parties (Althaus \& Tewksbury, 2002). This calls for the media to stay detached by simply presenting issues with facts objectively, sadly, as reported by the sampled participants in this current study, this is not the case in Nigeria. The above comments also suggest that newspapers in Nigeria tend to be more objective 
in reporting the conflict more than the Radio and TV. This is contrary to one content analysis, which conclude that newspapers in Nigeria, report inter-group conflicts with unprofessional acts of sensationalism, considerations of context, inaccuracy, unfairness, imbalance, incompleteness, less integrity and responsibility (Ciboh, 2015).

\section{Media in Nigeria contribute to the escalation of the herdsmen and farmers conflict}

According to the respondents, the sensationalism, lack of objectivity, factuality and negative usage of the language of reportage characterized by the Nigeria media is contributing to the escalation of the conflict rather than making it better. They stated that the Nigerian media is full of blame game than peace journalism. As far as this crop of respondents are concerned, Nigerian media most especially the private media are tools in the hands of the owners used to fight the government of the day. While the government media keeps beating drum for the ruling class. For example, they stated the case of Benue state and Taraba in which many media houses in Nigeria kept blaming the governors for the Anti open grazing, instead of looking for a better way to resolve the conflict. The respondents also mentioned that the manner in which media outlets frame the issue of the herdsmen-farmers in Nigeria contribute to the escalation of the conflict. For instance, words like crocked 'Fulani herdsmen attack unarmed farmers', 'farmers attack Fulani herdsmen wives and stole cattle's, 'terrorists-herdsmen', 'Fulani mercenaries, 'innocent farmers', 'defenseless farmers', 'bloodbath', 'drums of war', etc. All these words and several others do help in escalating the conflict rather than deescalating it. One respondent expressed that:

The way and manner the Nigerian media frame the issues of farmers and herdsmen in contribute in escalating the conflict rather than deescalating. It is full of sensational themes which could tear the country apart if care is not taken. (Participant 55)

In line with this another respondent stated that:

The negative use of language of reportage in the Nigeria media is contributing to the escalation of the conflict rather resolving it. The media ought to be a channel for conflict resolution, but that is not the case with the Nigerian media. (Participant 20)

These comments suggest that the Nigerian media manner of reportage constitute a factor that is contributing to the conflicts in Nigeria. Their reports are full of insightful words that could trigger conflict instead of manage it. According to Adisa (2012), the media's lack of carefulness in language could contribute to conflicts, and in media coverage of conflicts, words such as 'vicious', 'fundamentalists', 'Islamists', 'extremists', 'fanatics', 'barbaric', 'militants', 'rogues', 'terrorists', etc. should be avoided. Howard 
(2003) recommends that journalists should be very careful in their language use when reporting conflicts so as not to fuel it. This is not the case in Nigeria as some sections of the media in Nigeria only facilitates the escalation of the conflict through their horror use of language that insight more violence. As shown in prior study, this problem has cast doubts in the minds of both Christians and Muslims on the proper role of media reportage during ethno-religious conflicts (Barde, 2016). Thus, the rationale for reporting conflict has been shown to include the creation of awareness of a conflict to avoid escalation, in turn, helping religion and community leaders resolves conflicts; generating ideas on how best to reduce conflict; exposing the perpetrators and sponsors of conflict; de-escalating rather than to increase the conflict; to attract humanitarian responses through publicising yearning of aspirations of victims; and to provide early warning to law enforcement agencies and stakeholders so as to halt an incoming conflict (Pate, 2002). This is totally different from the case of Nigerian press as far as the sampled public is concerned.

\section{In-depth reporting of conflict victims'suffering is still lacking}

The respondents were asked to comment on the Nigerian media reporting of their suffering after a conflict occurs. The entire respondents commented that the media does not report their yearning, aspiration and suffering. The media only report in a surface manner without in-depth reporting of the conflict and as earlier mentioned they do not report the event again after the conflict has subsided. One respondent expressed that:

The Nigerian media be it radio, TV and print have less interest in reporting our suffering after a conflict occurs. They only report the issue the day it happens without further investigation of the properties lost. I believe if the media reports on our suffering it will attract humanitarian responses. (Participant 41)

Drawing from the above remarks, it could be deduced that the Nigerian media do not have much interest in the reporting of the suffering of the conflict victims and only report the issues the moment it happens without further investigations. It has been shown that the reason for conflict reporting should be to attract humanitarian responses through publicizing yearning and aspirations of victims (Pate, 2002). Relating these findings to the two theories used in this study, it could be said that journalists are mandated to give an accurate account of the farmers and herdsmen's conflict as well as give prominence and adequate frequency to the stories so that people will be on guard as well as attract assistance from the public. However, the way the Nigerian media are handling the case of the conflict shows a high level of unprofessionalism and negligence.

\section{Conclusion and recommendations}

This study is necessitated by the fact that despite the considerable articles written about the crisis on herdsmen and farmers and the role mass media have played, surprisingly, there is a dearth of research on people's perception as regards the media coverage of 
herdsmen and farmers conflict in Nigeria. Thus, this study filled the gap and it is based on the findings drawn from the perspective of the sampled conflict victims from three large conflict-prone communities in the North central of Nigeria. Overall, it provides another dimension of research finding beyond the predominant content analysis carried out in prior studies. This study applies the agenda and the social responsibility premise, which calls on journalists to give an accurate account of the farmers and herdsmen's conflict as well as give prominence, adequate frequency, and guard against the use of language that will insight more conflict.

Results obtained from this study, however, suggest a lack of prominence to the issue of herdsmen and farmers conflict in Nigeria. Nevertheless, the private media seem to allocate more prominence than the government media stations and overall, among the conventional media, radio stations, give more prominence to the issues of herdsmen and farmers conflict in Nigeria. Astonishingly, the new media such as blogs, Facebook, Twitter, etc., which has given rise to citizen journalism was said to cover the issues of the conflict more than the conventional media in Nigeria. Thus, blogs, Facebook, Twitter, provide an avenue for the public to create, frame and disseminate news content on the conflict, which in turn may attract more humanitarian responses.

Findings further indicate that Nigerian journalists do not integrate the premise of agenda setting in their practice. This implies that the media engage more on episodic reporting of herdsmen-farmers conflict. Evidence from the conflict victims indicate that the media cover the conflict when it is on but, as soon as the conflict is over, little or no attention is paid to other issues on the conflicts. Findings also showed a lack of objectivity and low factuality in the media coverage of herdsmen-farmers conflict in Nigeria. The conflict victims emphasized that the conventional media in Nigeria do not cover the issues of herdsmen and farmers conflict in an objective and factual manner. They stressed that journalists are mostly not present at the conflict-affected communities to cover stories, yet, they report such conflicts in the media, relying solely on the information obtained from security agencies.

Further results showed that in-depth reporting of the conflict victims' suffering is still lacking as their yearning, aspiration and grief are less covered. This suggests a lack of investigative reporting and social responsibility. This lack of social responsibility is further shown as most media practitioners in Nigeria interview either the farmers or herdsmen without hearing from both sides, resulting in sensationalised and unneutral reporting which contributes to the escalation of the conflict. The conflict victims also observed that the excessive use of negative language, which often indicate blame game, contributes to the escalation of the conflict.

Based on the outcome of this study,there is an urgent need to encourage journalists in Nigeria to be socially responsible to write and report for the benefit of the society and the country. Conflict reporting in Nigeria should be based on peace journalism, which 
entails propagating the message of reconciliation, negotiation and diplomacy. We therefore call on media practitioners such as editors and reporters to demonstrate a vital role in writing conflict stories without inciting more violence, but rather uncover the causes of conflict and discover the actual goal of all parties involve as well as safeguard the plight of the victims. They should provide multiple viewpoints on the issues of herdsmen and farmers conflict and demonstrate a desire towards solving than intensifying the conflict. Derogatory languages should be completely avoided, but rather provide contextual and background information to assist the public grasp the story in full.

\section{References}

1. Abdulbaqi, S. S., \& Ariemu, O. (2017). Newspapers framing of herdsmen-farmers' conflicts in Nigeria and its implication on peace-oriented journalism. Creative Artist: A Journal of Theatre and Media Studies, 11(2), 77-105.

2. Adamu, L. S. (2017a). Public perception of the media coverage of 2016 herdsmen and farmers 'conflict in Bokkos plateau state. PLASU Journal of Communication Studies, (3), 77-94.

3. Adamu, L. S. (2017b). The Media's Role in Quelling Violent Conflict Involving Youths as Foot Soldiers: A Content Analysis of News Report on Boko Haram Suicide Bombers and Civilian Joint Task Force-CJTF. International Journal of Innovative Research and Development, 5(9), 18-32.

4. Adisa, R. S. (2012). Land use conflict between farmers and herdsmen-implications for agricultural and rural development in Nigeria. INTECH Open Access Publisher.

5. Adisa, R. S., \& Adekunle, O. A. (2010). Farmer-herdsmen conflicts: A factor analysis of socio-economic conflict variables among arable crop farmers in North Central Nigeria. Journal of Human Ecology, 30(1), 1-9.

6. Afolabi, R. B. (2010). Mass media coverage of crises in Nigeria. Journal of Conflict Studies, 8(5), 51-65.

7. Akpan, F. U., Ering, S. O., \& Olofu-Adeoye, A. (2013). The media and conflicts in Nigeria. International Journal of Asian Social Science, 3(11), 2279-2287.

8. Althaus, S. L., \& Tewksbury, D. (2002). Agenda setting and the "new" news: Patterns of issue importance among readers of the paper and online versions of the New York Times. Communication Research, 29(2), 180-207.

9. Apuke, O. D. (2018). The role of social media and computational propaganda in political campaign communication. Language \& Communication, 5(2), 225-250.

10. Barde, M. W. (2016). Effects of media reportage of Ethno religious conflicts on Christians and Muslims in Kaduna state, Nigeria. (Master's thesis), Ahmadu Bello University, Nigeria.

11. Beetseh, K., Tion, S. D., \& Terwase, V. M. (2018). Herdsmen/Farmers Crises in Nigeria: The Role of Librarians in Resolving Crises. Library Philosophy and Practice, 1, 1-16.

12. Braun, V., \& Clarke, V. (2006). Using thematic analysis in psychology. Qualitative research in psychology, 3(2), 77-101. 
13. Braun, V., \& Clarke, V. (2013). Successful qualitative research: A practical guide for beginners. London: Sage.

14. Ciboh, R. (2015). Framing the herdsmen-farmers' conflicts and peace building in Nigeria. Mkar Journal of Media and Culture, 2 (2), 22-32.

15. Dauda, S., \& Omar, B. (2015). News sourcing of the 2011 Somali famine: A comparison between Panapress and Reuters. Global Media Journal-Malaysian Edition, 5(1), 77-97.

16. Flynn, M. A., Craig, C. M., Anderson, C. N., \& Holody, K. J. (2016). Objectification in popular music lyrics: An examination of gender and genre differences. Sex roles, 75(3-4), 164-176.

17. Folarin, B. (1998). Theories of mass communication: An introductory text. Ibadan: Stirling-Horden Publishers.

18. Gever, C. V., \& Essien, C. F. (2019). Newspaper coverage of the herdsmen-farmers conflict in central Tiv Land, Benue State, Nigeria. Media, War \& Conflict, 12(1), 102-120.

19. Gilboa, E. (2009). Media and conflict resolution: a framework for analysis. Marq. L. Rev., (93), 87, 15-22.

20. Gorman, G. E., Clayton, P. R., Shep, S. J., \& Clayton, A. (2005). Qualitative research for the information professional: A practical handbook. London: Facet Publishing.

21. Himelfarb, S., \& Chabalowski, M. (2008). Media, Conflict Prevention and Peacebuilding: Mapping the Edges. Washington: United States Institute of Peace.

22. Howard, R. (2003). The power of the media: A handbook for peacebuilders. European Centre for Conflict Prevention.

23. Idowu, A. 0. (2017). Urban violence dimension in Nigeria: Farmers and herders' onslaught. Agathos, 8(1), 187-199.

24. Kontagora, H. L., Watts, M., \& Allsop, T. (2018). The management of Nigerian primary school teachers. International Journal of Educational Development, 59, 128-135.

25. Marietu, E. T., \& Olarewaju, O. I. (2009). Resource conflict among farmers and Fulani herds men: Implications for resource sustainability. African Journal of Political Science and International Relations, 3(9), 360-364.

26. McQuail, D. (2010). McQuail's mass communication theory. London: Sage publications.

27. Odunlami, D. (2017). Sleeping on the Feet with Open Eyes! Newspaper Coverage of the Fulani Herdsmen/Farmers' Conflict in Nigeria. AGOGO: Journal of Humanities, 2, 29-37.

28. Ojewunmi, 0. (2013). 23 killed in fresh herdsmen crises in Plateau State, 25 January. http://www.naijalatestnews.com/23-killed-in-fresh-fulani-herdsmen-crises-in-pla teau-state.

29. Okello, A. L., Majekodunmi, A. O., Malala, A., Welburn, S. C., \& Smith, J. (2014). Identifying motivators for state-pastoralist dialogue: Exploring the relationships between livestock services, self-organisation and conflict in Nigeria's pastoralist Fulani. Pastoralism, 4(1), 12-22.

30. Oladimeji, Y. U., Abdulsalam, Z., Damisa, M. A., \& Omokore, D. F. (2015). Estimation of efficiency differentials in artisanal fishery: implications for poverty reduction in selected States in North Central, Nigeria. Nigerian Journal of Basic and Applied Sciences, 23(2), 121-128. 
31. Ozuhu-Sulaiman Y. (2013). Media and peace building in Israel/Palestine: An empirical study. Kaduna: Rich values Concept Ltd.

32. Parajuli, R., \& Doneys, P. (2017). Exploring the role of telemedicine in improving access to healthcare services by women and girls in rural Nepal. Telematics and Informatics, 34(7), 1166-1176.

33. Pate, U. A. (Ed.). (2002). Introduction to Conflict Reporting in Nigeria. Nigeria: Frankad Publications.

34. Pate, U. A., \& Dauda, S. (2015). The Media, Responsibility and Conflict-Sensitive Reporting in Nigeria. Emerging Trends in Gender, Health and Political Communications in Africa. A Book in Honour of Professor Ike Ndolo. Enugu: Rhyce and Kerex Publishers, 214-228.

35. Reynolds, A., \& McCombs, M. (2002). News influence on our pictures of the world. In Media effects, Bryant, J., \& Oliver, M. B. (Eds.). (2009). (pp. 11-28). Routledge.

36. Ross, K. (2007). The journalist, the housewife, the citizen and the press: Women and men as sources in local news narratives. Journalism, 8(4), 449-473.

37. Shehu, A. (2017). Newspapers Coverage of Herders/Farmers Conflict in Nigeria. International Journal of Communication, 22(1), 12-22.

38. Stake, R. E. (2013). Multiple case study analysis. New York City: Guilford Press.

39. Sundin, E. (2015). The role of media content in everyday life. To confirm the nearby world and to shape the world beyond our reach. Journalism, Representation and the Public Sphere, 83.

40. Udeze, S. E., \& Chukwuma, O. (2016). Audience assessment of broadcast media surveillance and national security in Nigeria. Covenant Journal of Communication, 1(2), 22-32.

41. Vladisavljević, N. (2015). Media framing of political conflict: A review of the literature. Working Paper. MeCoDEM. ISSN 2057-4002 (Unpublished).

42. Zeng, L., Agwaziam, N., \& Xiao, Z. (2014). Framing the Jos Crisis in Nigeria: A Comparative Analysis of the Punch, the Guardian and This day. International Communication Research Journal, 49(1-2), 2-20. 